\section{Archivos de \\ Ciencias \\ Educación}

Archivos de Ciencias de la Educación ISSN: 2346-8866

revistaarchivos@fahce.unlp.edu.ar

Universidad Nacional de La Plata

Argentina

\title{
Introducción a la conferencia de Adriana Puiggrós
}

\author{
Fernández Pais, Mónica \\ Introducción a la conferencia de Adriana Puiggrós \\ Archivos de Ciencias de la Educación, vol. 13, núm. 16, 2019 \\ Universidad Nacional de La Plata, Argentina \\ DOI: https://doi.org/10.24215/23468866e070
}

Atribución no comercial compartir igual (CC BY-NC-SA) 4.0 
Adriana Victoria Puiggrós es una pedagoga argentina comprometida con la política educativa nacional y de América Latina. Exiliada en México en la última dictadura cívico militar argentina, en 1981 crea el "Programa Alternativas Pedagógicas y Prospectiva Educativa en América Latina (APPeAL)" en la Universidad Autónoma de México. En su regreso a Argentina el Programa se constituye en un espacio de investigación y producción de saberes pedagógicos desde una perspectiva latinoamericana en diálogo con la praxis política. Sus aportes han abonado la configuración de los estudios de historia de la educación y el desarrollo de categorías a partir de las cuáles comprender de modo estructural los procesos de la historia de la educación desde una perspectiva crítica promoviendo la participación activa en espacios de transformación social.

Sus aportes al estudio de la educación popular a partir de las categorías freireanas han trazado una línea de pensamiento desde la década de 1970 en la Universidad Nacional Autónoma de México en función de la necesidad de atender el analfabetismo que afectaba a México y Centroamérica por aquellos años (Puiggrós, 2013, p. 10). Es en ese campo de estudios de la educación popular donde el pensamiento del pedagogo brasileño Paulo Freire se magnifican. Si bien Freire no llega a desplegar una nueva teoría, Puiggrós advierte que su legado ayuda a construir "un nuevo imaginario". La pedagoga argentina señala:

Freire pone en juego una visión de la educación que realmente cambia las coordenadas, cambia el orden de los sujetos; y toma un punto, a mi manera de ver, central, que es la posibilidad de la educación, del intercambio de lugares entre el sujeto educador y el sujeto educando. Esa es una de las cuestiones centrales que plantea Paulo Freire. Porque el concepto de 'educación dialógica' pone en crisis la educación moderna, dado que un pilar de la educación moderna es el lugar del maestro, el lugar del educador, el lugar del profesor; el lugar del saber está en el lugar del profesor (Ibid., p. 11).

En su búsqueda permanente por trazar mapas que conduzcan desde la teoría al análisis político y, desde allí, a la realidad, la reflexión puiggrosiana nos invita a pensar que desde 1967, año en el que Freire publica $L a$ educación como práctica de la libertad, hasta la América Latina de Luiz Inácio "Lula" da Silva y Néstor Kirchner en 2003, existen líneas de continuidad trazadas por aquellos hombres cuyas utopías buscaban romper las cadenas que unen la educación con el capitalismo. De esta manera, sus trabajos ayudaron a estudiar a Paulo Freire como un hombre que abonó a la educación emancipadora como realidad posible.

En 1985, Freire publica en São Paulo junto a Frei Betto Essa escola chamada vida: Depoimentos ao repórter Ricardo Kotscho, allí ambos develan los modos en que en circunstancias diferentes desarrollan una acción educativa cuyos protagonistas son los sectores oprimidos. Fue Adriana Puiggrós quien prologó la versión traducida al español y publicada por editorial Legasa de Buenos Aires en 1988 con el nombre "Esa escuela llamada vida", en la que decía:

Hace treinta años, en un pequeño pueblo del nordeste brasileño, un maestro católico comenzó una experiencia. El informe oficial dice que inventó un método de alfabetización rápida, que molestó a algunos y asustó a muchos. En realidad, existe otra forma de interpretar lo que sucedió ahí, y puede decirse, que hubo un descubrimiento trascendental para la historia de la educación de los pueblos oprimidos. También encierra un cuestionamiento moral al liberalismo positivista latinoamericano. Se descubrió que la relación de asimetría entre el maestro y el alumno no era un elemento que formaba parte de la naturaleza misma de la educación. Esa relación había sido históricamente construida. Otro elemento fue que la política no es un 
elemento externo al proceso educativo, no se trata de subsistemas que inciden mutuamente, como pretende el funcionalismo. Tampoco se trata de un campo inerte, que recibe el reflejo del espacio en el cual se generan los procesos verdaderos, reales, materiales. El elemento político es parte indisociable del pedagógico, es un elemento constitutivo del mismo (1988, p. 55-56).

De este modo, Puiggrós introducía en la Argentina la obra de un hombre atravesado por las propias experiencias vitales, el compromiso con los sectores más vulnerados, la búsqueda constante de cambio social y la creación conceptual.

En 1989 Puiggrós regresó a la Facultad de Facultad de Filosofía y Letras de la Universidad de Buenos Aires al acceder por concurso al cargo de profesora titular de Historia de la Educación Argentina y Latinoamericana, desde su quehacer recupera y proyecta el pensamiento de Paulo Freire. Dirá Puiggrós sobre esos inicios:

Ya en el grupo de APPEAL-México habíamos sentido la necesidad de conocer a fondo la historia de la educación latinoamericana para encarar su prospectiva. El Programa nació con un fuerte tinte latinoamericanista, influido por la teoría de la dependencia, el flujo de las discusiones provocadas por Paulo Freire sobre la educación popular y las lecturas de los historiadores latinoamericanistas y antiimperialistas (2015, p. 225).

Años más tarde Puiggrós avanza en trazar los primeros recorridos en las líneas del pensamiento pedagógico latinoamericano en el ensayo "De Simón Rodríguez a Paulo Freire", por el cual recibió el Premio Andrés Bello de Memoria y Pensamiento Iberoamericano, convocado por el Convenio Andrés Bello en 2004 y publicado en 2005. En el mismo, la autora afirma la necesidad y posibilidad de fundar una historia de la educación y, sostenemos, una pedagogía que incluyera la vocación latinoamericanista, caribeña e hispanoamericana capaz de potenciar los ideales de dos hombres, dos idealistas que deben ser estudiados para imaginar otros universos educativos posibles en el presente y el futuro (2010, p. 113).

Su trayectoria en el campo de estudios pedagógicos la llevó a acuñar categorías como la de sujeto pedagógico, fructífera tanto para los estudios de historia de la educación como para la comprensión del alcance de los planteos freireanos. En sus trabajos plantea una mirada del hecho social singular por su inevitable vinculación con la educación, ya que según sus palabras: "Todo hecho social tiene una lectura pedagógica y en todo proceso social, en todo discurso social en el sentido más amplio del término, hay un registro pedagógico" (Puiggrós en Zysman y Peluso, 2015, p. 206).

Profesora Honoris Causa de la Universidad Nacional de La Plata, miembro del Consejo Internacional de Asesores del Instituto Paulo Friere, la doctora Adriana Puiggrós nos honra como miembro de la Cátedra Libre Paulo Freire creada por Resolución 1465/2018 por el Consejo Superior de esa universidad. Integrada por representantes de distintos campos del saber, la Cátedra ha transitado un primer año de tareas en el que se abocó a la organización y el homenaje al legado freireano con la visita del Premio Nobel Adolfo Pérez Esquivel (UNLP), la presentación del libro de Walter Kohan, Paulo Freire, más que nunca. Una biografía filosófica y las articulaciones para la conmemoración del centenario del natalicio del brasileño junto a la CTERA y la Internacional de la Educación.

La participación de Adriana Puiggrós en la apertura de la Cátedra y su constante tarea en pos de la difusión del pensamiento latinoamericano y activa participación en la política educativa del país, no hacen más que comprometernos con la difusión de un legado que se vuelve amenaza para los proyectos neoliberales y esperanza para las propuestas de los pueblos al sur del Río Bravo. Las discusiones en torno a Paulo Freire y sus ideas se vuelven intimación en los países en los que las prospectivas son dictadas por el mercado y los totalitarismos y sinónimo de libertad en los espacios de producción de conocimiento y formación intelectual.

Ante un escenario mundial complejo y un futuro en el que se avizoran las pérdidas de certezas, volver a Paulo Freire se vuelve refugio y horizonte de posibilidades. Desde la Cátedra Libre, Puiggrós nos convoca a la reflexión fecunda y pronta al decirnos, exhortarnos a nuevas reelaboraciones o producción de nuevas teorías inspiradas en las ideas freireanas (2019, p. 56). Nos invita a abrir caminos de pensamiento crítico y de investigación acción participante. Asumimos ese reto y nos convocamos a la tarea... 


\section{REFERENCIAS}

Puiggrós, A. (1988).Prólogo. En Freire, P. y Frei B., Esa escuela llamada vida (pp. 9-63). Buenos Aires: Legasa.

Puiggrós, A. (2010). De Simón Rodríguez a Paulo Freire. Educación para la integración latinoamericana. Buenos Aires: Colihue.

Puiggrós, A. (2013). Enfoques para la educación latinoamericana en el siglo XXI.En Rodríguez, L. (Dir.), Educación popular en la historia reciente en Argentina y América Latina (pp. 9-18). Buenos Aires: APPEAL.

Puiggrós, A. (2015). Memoria sobre los orígenes de la Historia de la Educación en la Argentina. Historia de la Educación Argentina, Galerna (1990-1997). En Arata, N. y Ayuso, M. L. (Ed.), SAHE 20, La formación de una comunidad intelectual, (pp. 223-227). Buenos Aires: SAHE.

Puiggrós, A. (2019). La escuela plataforma de la patria. Buenos Aires: Unipe-CLACSO.

Zysman, A. y Peluso, N. (2015). La irreverencia en la Historia de la Educación Latinoamericana. Conversación con Adriana Puiggrós". En Arata, N. y Ayuso, M. L. (Ed.), SAHE 20, La formación de una comunidad intelectual (pp. 205-213). Buenos Aires: SAHE.

\section{BY-NC-SA}

